\title{
Economic analysis of fuel cell installations at commercial buildings including regional pricing and complementary technologies
}

\author{
Dustin McLarty $^{a *}$, Jack Brouwer ${ }^{\mathrm{b}}$, Chris Ainscough ${ }^{\mathrm{c}}$ \\ ${ }^{a}$ Clean Energy Systems Integration Laboratory, Washington State University, Pullman, WA 99164 \\ ${ }^{\mathrm{b}}$ National Fuel Cell Research Center, University of California, Irvine, CA 92697, USA \\ ${ }^{c}$ U.S. Department of Energy, 1617 Cole Blvd, Golden, CO 80401 USA \\ *corresponding author dustin.mclarty@,wsu.edu \\ Keywords: \\ energy economics, fuel cells, commercial buildings, market analysis, complementary technologies, energy storage
}

\begin{abstract}
This paper presents results from sensitivity studies conducted using the Distributed Generation Build-out Economic Assessment Tool (DG-BEAT). The viability of meeting commercial building loads with a stationary fuel cells is studied under different conditions of electricity pricing, dispatch strategies, and complementary technologies. Key findings support the notion that fuel cells are becoming economically viable alternatives in California, New York and Connecticut at installed costs of $\$ 7,000-\$ 10,000 / \mathrm{kW}$. Michigan is identified as another state well suited to fuel cell development with heat recovery. Fuel cell installations reduce net carbon emissions for commercial buildings by 20-30\% when compared to local, time-resolved, grid emissions. Grid sell-back, at 50\% retail price, significantly improves the economics of a base load fuel cell, but has little impact for a dispatchable system. At installed costs below $\$ 5,000$ per $\mathrm{kW}$, load following capability results in significant additional cost reductions as the generating capacity is increased beyond the building's base load requirements. Complementary technologies such as chillers and thermal storage have a pronounced impact, particularly in warmer climates. Installing fuel cells paired with electric chillers and thermal storage in Florida at buildings with exceptionally high air conditioning demands can achieve the same economic benefit as a typical New York building.

Nomenclature

CHP Combined Heat and Power

DG Distributed Generation

DG-BEAT Distributed Generation Buildout Economic Assessment Tool

FC Fuel Cell

$\mathrm{kW} \quad$ kilowatt

MW megawatt

NPC Net present cost

SOFC Solid Oxide Fuel Cell

TES Thermal Energy Storage

TOU Time of Use

Variables

$t_{o n} \quad$ Begin of on-peak electricity rates

$t_{\text {off }} \quad$ End of on-peak electricity rates

$r_{o n} \quad$ Duration of ramp from off-peak

output to on-peak output

$r_{\text {off }} \quad$ Duration of ramp from on-peak

output to off-peak output

demand $_{t}$ Demand at time interval $t$

$D G_{t} \quad$ Output at time interval $t$
\end{abstract}




\section{Introduction}

This paper presents analyses conducted using the Distributed Generation Build-Out Economic Assessment Tool (DG-BEAT) [1]. The aim of this paper is to perform sensitivity analyses of the primary factors influencing the economic viability of stationary fuel cell systems for commercial buildings in the United States. Some of the important factors identified by others and that are also considered here include: commercial electricity and gas rates [2], timeof-use and demand charges, building dynamics, climate impacts, fuel cell control capability $[3,4,5]$, and balance of system components such as thermal or electric energy storage [6,7] and absorption chiller heat recovery [8,9].

Briefly, the DG-BEAT tool performs a detailed energy dispatch to meet an entire year of high resolution (15minute) building energy data developed in Energy Plus [10,11]. The dispatch considers key constraints such as generator ramp rates and turndown ratios, grid interconnection limits, and energy storage charging/discharging inefficiencies. Non-linear efficiency curves are interpolated to determine annual energy use, emissions, and costs corresponding to the dispatch. The same analysis features can be applied to a variety of distributed generation technologies used to meet a portion or all of the energy demands at a single building or multiple buildings (e.g., campus). Balance of system components (e.g., absorption chilling, energy storage) change the dynamics of buildinggenerator system by coupling or de-coupling the generation with cooling demands or electric demands.

Generator dynamics and dispatch are supported by physical modeling experience [12,13,14], and coupled with datasets for renewable energy generation (e.g. insolation and wind speed profiles) [15,16], utility rate structures [17], spatially and temporally resolved grid emissions of $\mathrm{CO}_{2}, \mathrm{NO}_{x}$, and $\mathrm{SO}_{x}[18]$. The distribution of commercial buildings in all 50 states is divided into sixteen categories. A detailed description of the open access software, DG-BEAT, can be found in [1].

Stationary fuel cells have been successfully deployed at a number of commercial buildings including supermarkets [19], office buildings [20], and hotels [21]. Many of America's largest companies are deploying stationary fuel cells in applications ranging from data centers to onion processing [22]. Additional commercial applications for which fuel cells have demonstrated economic viability such as biogas applications at wastewater treatment [23] and landfill facilities, backup power [24], and tri-generation with co-production of hydrogen [25] are not currently considered. Residential fuel cell applications require an order of magnitude cost reduction to become cost effective [26,27] and are not considered at this time.

Analyses of stationary fuel cell systems have often considered only the electric output, while some have included an SOFC with hydrogen co-production [4], electric energy storage [7], thermal storage [28] or absorption chilling [8]. Some limited sensitivity studies suggested a strong dependence upon the relative costs of electricity and natural gas, the presence of net-metering tariffs, and additional CHP systems e.g. electric and thermal storage [4]. Absorption chillers were shown to be well suited for thermodynamic integration with high temperature fuel cells although the economic benefit is undetermined [9]. The literature suggests potential for improved economic performance from applying a dispatchable fuel cell to a building demand using either a simple [29] or complex physical model of the system [3].

Most prior assessments of DG technology agree that only specific combinations of local energy costs, building type, DG system and dispatch strategy result in energy, cost, and emissions savings to buildings. Simulations are typically conducted on a case-by-case basis. In an effort to accelerate the simulation process, an analysis by Pruitt et al. developed a series of mathematical formulas for the determination of savings and losses using just a few characteristics of the building profile and rate structure [2]. The current work supports the findings of these previous studies and further expands upon the comparative study capabilities of the literature with a substantially more rigorous methodology and consideration of a much broader set of buildings, generators, and energy rates.

The largest factor impacting the economic viability of fuel cells is the value of energy conversion, calculated as the difference between the local fuel (i.e. natural gas) and electricity prices. Error! Reference source not found. presents this value for the commercial sector, utilizing the same energy cost projections as DG-BEAT. The local favorability to distributed generation technologies is illustrated with respect to a baseline "spark spread" determined from the national average for electric and gas energy costs, and is highly sensitive to changes in the future energy cost projections. Higher electric rates and lower gas rates are favorable to fuel cells. Most geographic analysis of fuel cell viability will reflect this value of energy conversion, see for example Error! Reference source not found.. Thus, to 
identify impacts of different operating modes and complementary technologies, most results are presented as comparisons to the initial baseline case of Error! Reference source not found..

$* * *$ Insert Figure \#1 here **

These seven scenarios, mapping features, and national commercial building datasets are included features of the DG-BEAT tool, and can be readily repeated with generator specific costs and performance as well as specific financing terms and updated utility pricing or forecasts. Further inquiries into specific features of each state, or the impact of various state incentives [17], are relevant to fuel cell deployment but omitted here due to their temporary nature. This work brings focus to broader regional trends and DG system design considerations.

\section{Methodology}

This study presents seven test cases evaluated using the national analysis feature of DG-BEAT. Numerous scenarios were evaluated, but the scenarios presented in Error! Reference source not found. were selected to illustrate particularly relevant impacts on the stationary fuel cell market. All scenarios outlined in Error! Reference source not found. included a generic SOFC module with $60 \%$ fuel-to-electric conversion efficiency. Heat recovery, to an exhaust temperature of $100^{\circ} \mathrm{C}$, is applied to the heating demand coincident with the electric generation. Scenarios 6 and 7 consider the addition of electric chillers with thermal storage or the addition of an absorption chiller. Scenarios 1, 4 and 7 consider a fixed price of purchased electricity, while scenarios 2, 3, 5, and 6 consider time-of-use (TOU) pricing. All seven scenarios include a simulation of 16 building varieties across the lower 48 states. The unique energy costs and climates in Alaska and Hawaii merit separate analysis.

Each simulation consisted of loading the appropriate building energy profile, specific to each states climate, determining the fuel cell and balance of system capacities (i.e. chillers, thermal storage, batteries) according to the control strategy and export allowances, dispatching the energy systems according to the control strategy and export allowances, calculating the baseline and dispatched costs and emissions, and performing a net-present-cost analysis of the buildings energy expenses over the lifetime of the DG system.

*** Insert Table \#1 here **

There are a variety of methods available to determine the size of the fuel cell and balance of system technology built into DG-BEAT. Error! Reference source not found. illustrates the trade-offs between several sizing methods. The presented trends are not precise but are indicative of the decision making considerations when sizing and operating a combined cooling, heating and power (CCHP) system. Meeting a greater proportion of the demand requires increasingly expensive technology to meet peak capacity and respond to building dynamics. The increase in size and decrease in operating hours of the self-generation technology causes an exponential rise in the relative equipment costs. As the self-generation is better utilized (operates a greater proportion of the time), energy and operations costs increase, while utility charges are reduced.

\section{*** Insert Figure \#2 here **}

The sum of these three curves results in a convex curve which can be optimized for one of three objectives: a) the maximum energy cost savings, b) the maximum potential emissions reduction for a given cost, and c) the quickest investment payback period. Determination of these points is specific to each building/state/DG installation combination and requires iteration between the building dynamics, generator performance, control strategy, and utility costs. For many installation sites in the United States the initial installation costs for a CCHP system are high enough that the energy costs with CCHP are never less than the grid alternative.

Alternative sizing options include setting the size to meet a fixed portion of building demand or designing the largest system that will not export power back to the grid at any time during the year. These simple sizing methods are typical in the marketplace, but, are not the economically optimal solutions and may result in a larger or smaller than optimal fuel cell system. The zero-export sizing methodology is preferable for presenting the national trends covered in this paper since the sizing is independent of utility rates, and many utilities are resistant to exporting self-generation onto the grid. 
The three dispatch algorithms (i.e. base load, load-following, and diurnal dispatch) are presented in Error! Reference source not found., adapted from [1]. For all scenarios except 4, the FC is sized to never export electricity. For the base load control strategy, Scenarios 1, 2, and 7, the FC is sized for the annual base load of the building. For Scenario 4, the fuel cell size is determined iteratively to find the best NPC savings assuming a 10 year plant lifespan and including the value of excess energy re-sold onto the grid. Scenarios 3, 5, and 6 size the FC relative to the onpeak (e.g. 8AM to 6PM) demand for weekdays in the summer (i.e. June to September).

*** Insert Table \#2 here **

When comparing states in the national analyses, the peculiarities of individual electric utility rate structures were avoided by using a single non-TOU (time of use) and single TOU rate structure. These two rate structures are scaled locally, and seasonally, to the average state energy costs for commercial users. Data is taken from EIA 2014 monthly electric and gas prices. Self-generation typically reduces energy charges by a greater fraction than demand charges, resulting in higher costs per $\mathrm{kWh}$ of utility purchased electricity. Capturing the changing ratio of energy/demand charges is critical to understanding the economic trade-offs of installing larger base load systems. Utility costs are projected forward 10 years using the historical 25 -year trend line for each state and adding the seasonal variation.

Error! Reference source not found. summarizes the component installation costs estimated from various manufactures [30,31], the operation and maintenance costs assumed to be equivalent to more established distributed technologies such as micro-turbines [32], and financing terms used in calculating the net present cost (NPC) of the baseline building and building with DG. Cost estimates for SOFC differ substantially based upon the stack size and production quantity. A fixed value of $\$ 1200$ per $\mathrm{kW}$ was chosen for the stack replacement cost based upon the recent analysis for auxiliary power units conducted by Batelle [33].

*** Insert Table \#3 here **

The break-even installation cost of the fuel cell was left as a calculated variable. The grid parity cost of the FC was determined by balancing the net present costs of the building with and without DG. Thus the figures presented in the Results section represent the installed fuel cell cost that would deliver energy (i.e. electricity, heating, and cooling) to the average commercial building of the state at an equal price to the current electric and gas utilities of that state. If and when actual installed fuel cell costs are less than the indicated grid parity cost, then fuel cell installations become economically preferable for a majority of the commercial buildings within the state.

The results presented are the weighted average of all commercial buildings within the state accounting for all of the individual building-generator dynamics. The raw values for all 16 buildings in each state are weighted by the proportion, in annual energy use, that each building type contributes to the state total. As such, some building types and locations may justify a fuel cell installation well before it is economically preferred for the 'average' building in a particular state. Additionally the systems in all scenarios, except Scenario 4, do not represent the cost optimal installation size, and a more economically preferable size may be found. A negative FC cost represents a losing proposition, where regardless of the FC cost, the installation would be financially unsound. The unquantified air quality, carbon emissions, and reliability improvements, or location specific energy costs may support FC installations in these states, despite the financial loss for the 'average' commercial building.

\section{Results}

\subsection{Baseline Results}

Scenarios $1 \& 2$ consider a fuel cell sized to the base load demand of each building. The fuel cell is operated continuously at full output in both cases, while the electric rate switches between non-TOU and TOU. For most buildings the majority of the demand greater than the building base load occurs during peak hours, and is subject to higher rates in scenario 2. Since this constitutes a greater portion of the purchased electricity when the fuel cell is installed, the effective electric rate is higher, and the net energy costs offset by the FC are reduced. Thus the grid parity cost (i.e. the FC cost resulting in equal net present costs for the grid only and grid supported FC cases) is lower when TOU rates are applied. The generic TOU rate also has higher demand charges which has the same effect for highly 
dynamic building profiles (e.g. restaurants and strip-mall retail stores), and minimal effect for less dynamic buildings such as a hospital.

Error! Reference source not found. presents the grid parity costs for Scenario 2: base load fuel cell with TOU electric rates. This is considered the baseline since most utility companies have transitioned commercial customers with self-generation to some variety of TOU pricing. Higher grid parity cost is better for a fuel cell installation since these areas will tend realize an economic benefit at higher fuel cell prices of $\$ 7,000-\$ 10,000 / \mathrm{kW}$, and a larger benefit when prices are reduced or incentivized. The calculated grid parity cost does not consider any local or federal incentive programs, but does consider the building profile, fuel cell efficiency, escalating natural gas and electric rates, financing and maintenance costs including stack replacement at 5 years. The results of 800 annual simulations of building/state combinations have been weighted by the proportion of a state's base load attributable to each building type. The cost parity map for Scenario 1 looks quite similar to that shown for Scenario 2 (Error! Reference source not found.) with grid parity costs $\$ 1500$ - $\$ 2500$ higher; however few utilities would offer non-TOU rates to commercial buildings with on-site generation. The grid parity cost is specified per $\mathrm{kW}$ of installed FC capacity, and represents the installed fuel cell cost which results in zero net-present-cost savings over the 10-year lifetime of the fuel cell.

*** Insert Figure \#3 here **

The Department of Energy's Office of Energy Efficiency and Renewable Energy has identified California, Connecticut, New York, Ohio, and South Carolina as the leaders in fuel cell deployment [30]. Not surprisingly, some of these same states demonstrated the highest grid parity $\mathrm{FC}$ costs on the map with values ranging from $\$ 7,300$ to $\$ 10,200$ per kW installed (Error! Reference source not found.). Ohio and South Carolina appear as less than ideal locations for stationary fuel cells, but progressive local policies or incentives have attracted significant fuel cell industry research, development and installations. The upper end of this grid parity cost scale, $\$ 7,000-\$ 10,000$, corresponds well with current unsubsidized installed fuel cell costs [31]. Cost projections as low as $1 / 5^{\text {th }}$ of these values are widespread and would substantially increase the market appeal of the technology [2]. In the past 5 years fuel cell system costs have been halved and future cost savings can be realized by manufacturing at greater scale [32]. Note these values are the weighted average for all commercial buildings within the state, and certain buildings such as apartment buildings and hotels, may be able to justify installed FC costs that are $\$ 1,000$ to $\$ 2,000$ higher.

Michigan is a surprisingly well-suited location for stationary fuel cells with a grid parity cost that is $\$ 300$ higher than California. Michigan also has the $8^{\text {th }}$ largest commercial building inventory of any state. Michigan has both high electric and high gas rates, but it is the nearly year-round heating demand that can be partially met by a combined heat and power (CHP) fuel cell that makes Michigan such an attractive location. Neighboring states with similar climates have considerably cheaper electric and gas rates, and do not see such high potential for CHP fuel cells. Massachusetts, New Jersey, and Rhode Island see similar grid parity costs as New York and Connecticut due to the similarly high electric rates.

Error! Reference source not found. also illustrates several regions, the south and northwest for example, that contain states exhibiting a negative grid parity cost largely due to inexpensive grid electricity. These states offer a definite challenge to the widespread cost effectiveness of stationary FC deployments, but are not prohibitive to niche markets which value additional features such as low environmental impact, low acoustical impact, or enhanced electric reliability.

Error! Reference source not found. illustrates the proportion, 30 to $45 \%$, of each state's commercial electric demand that could be displaced by distributed base load fuel cells. These values apply to Scenario's $1 \& 2$, and will be substantially higher for all other scenarios. States with mild or dry climates, such as California, or large numbers of apartment buildings, such as New York, have higher base loads. Buildings such as hospitals and hotels with steady year round energy demands are often ideal for base load installations [33].

\section{*** Insert Figure \#4 here **}

There is a strong correlation between the proportion of base load demand and the potential cost savings using stationary fuel cells. Smaller capacity systems, displacing 10-35\% of annual electric demand, improve reliability of critical systems, but may not offset sufficient energy costs unless the generation is highly responsive to peak load events and significantly reduces demand charges. Larger systems, displacing $40-75 \%$ of annual electric demand, may better justify the investment in self-generation. Without sellback to the grid, larger systems designed to displace more 
than $80 \%$ of annual electric use become cost-prohibitive. Displacing more than $80 \%$ of electric use requires either a low capacity factor or substantial energy storage (see Error! Reference source not found.).

There is no apparent correlation between building size and FC parity cost, however larger buildings may be more attractive candidates because large FC systems can achieve lower installed costs on a per $\mathrm{kW}$ basis, but the current method of comparison excludes this impact.

Error! Reference source not found. presents the same data from Scenario 2, but grouped by building type rather than state. Each building type demonstrates a positive FC parity price, thus indicating that the national average value of a base loaded stationary fuel cell is approximately $\$ 3500$ per $\mathrm{kW}$ installed. Price parity values for building categories within individual states range as high as $\$ 12,000$ and as low as $-\$ 2,500$ per $\mathrm{kW}$. The negative values indicate that despite a $60 \%$ conversion efficiency, a fuel cell cannot overcome the small price differential between natural gas and the coal-fired or hydro-electric plants powering the electric grid. Nationally, warehouses appear to be the least attractive building category for fuel cell installations, despite a nearly $50 \%$ base load. This is largely due to a complete absence of heating demands to be offset, and the placement of warehouses in locations with inexpensive energy costs.

\section{*** Insert Figure \#5 here **}

Academic and industry analysts, in-line with government targets, estimate future mass production costs to be $\$ 1,000$ per $\mathrm{kW}$, although this may be optimistic [34]. Considering permitting, installation, and insurance costs in addition to this manufacturing target cost should leave plenty of space for profit and savings under the $\$ 3,500$ national average break-even cost. For a specific location, there is a strong correlation between base load percent and the grid parity cost that is not apparent in this national-level analysis due to the uneven distribution of each building type among states. Individual site sensitivity analyses are important to identify these relationships which cannot be discerned solely from the national market and/or state-by-state analyses detailed herein. Interesting features are nonethe-less well discerned from each scenario when grouping the data by state or by building type. The remaining scenarios will be grouped by state, but features of both individual installations and state-wide averages will be discussed.

Annual emissions reductions depend upon the local grid emissions, the amount of grid electricity displaced, and the time of day the electricity is displaced. Error! Reference source not found. presents a map of the emissions reduction potential of Scenario 2. The map is nearly inverted from Error! Reference source not found. due to the high correlation of electricity costs and clean energy. The northwest provides an exception due to the abundance of low cost hydro power. Installing a base load fuel cell in a low carbon state, such as California, could reduce $\mathrm{CO}_{2}$ emissions by $21 \%$. The bulk of the carbon emissions associated with electricity in California occur during on-peak hours when a base load fuel cell is offsetting only a portion of the demand. California buildings could realize a $46 \%$ reduction in $\mathrm{CO}_{2}$ by installing a larger load-following fuel cell which meets significantly more on-peak demand. An appropriately sized system, tested in Scenario 5, will account for nearly $95 \%$ of the buildings annual electric demand, and nearly $90 \%$ of on-peak demand. The additional $\mathrm{CO}_{2}$ reduction comes at a cost. The fuel cell capacity factor is reduced to $66 \%$ and the cost of the FC installation must decrease from $\$ 9,000$ to $\$ 4,500$ per $\mathrm{kW}$ to realize an economic benefit.

\section{*** Insert Figure \#6 here **}

\subsection{Control Strategy Impacts}

The DG-BEAT tool includes 5 control strategies; a) base load, fixed power operation, b) weekend dip, a scheduled operation with full load on weekdays and part-load on weekends/holidays, c) diurnal dispatch, a dynamic daily scheduling in which the system is designed to meet the bulk of the on-peak hour demand with a single power setpoint, and operate at reduced power during the off-peak hours, d) a fully dynamic load following dispatch subject only to the ramp rate constraints specified for the generator and other equipment, and e) an emissions control algorithm developed to minimize the net carbon emissions attributable to the building using historical grid emissions as a reference.

Scenarios 1, 2, 4, and 7 utilize the simplest dispatch strategy, base load operation. Scenarios 3 and 5 consider diurnal dispatch and load following respectively. Both scenarios consider TOU energy pricing and do not allow sellback of excess energy. Error! Reference source not found. presents the dispatch algorithms for both control 
approaches. The primary difference to a building site with either of these control strategies is the installation of a larger fuel cell system that is not continuously operated at full capacity. Both diurnal dispatch and load following control strategies have previously been shown to be feasible for high temperature fuel cells $[5,4]$.

Sizing the system to mitigate additional energy and demand charges without excessively impacting the capacity factor requires an optimization which was not conducted for Scenarios 3 and 5. Previous studies have suggested the most economical means of operating a high temperature fuel cell is in a life preserving mode [29] and that diurnal operation may actually extend the lifespan by operating at reduced current [5]. Scenario 3 sized the fuel cell capacity to the minimum electricity demand during on-peak hours of the average summer weekday. Scenario 5 sizes the system to the average on-peak hour demand for a summer weekday. Both scenarios consider the turndown ratio and the minimum power demand of the year to avoid ever exporting power. This study finds additional cost savings for the majority of the buildings and states when a larger installation is operated on a daily schedule, rather than a smaller base-load unit.

The non-optimal sizing results in a relatively low capacity factor, $<60 \%$, and high proportion of self-generation, $>80 \%$, for Scenario 3. The system of Scenario 3 is substantially oversized, particularly in low cost energy markets, resulting in lower grid-parity costs than Scenario 2 for the primary candidate states of California, New York, and Connecticut. Elsewhere, installing a larger system that can turn down to part-load on a daily schedule resulted in additional savings for 438 of the 800 building/state combinations, but resulted in higher grid parity costs for only 269 cases ( $1 / 3$ of all buildings). The difference arises from the fact that the average installation capacity increased by $250 \%$ and the additional savings (10-50\%) are divided by a more quickly increasing installation size. For these 269 buildings, the additional energy cost savings, as much as $25 \%$ of the total energy costs, more than justifies the additional capital investment.

Error! Reference source not found. presents a comparison of Scenarios 2 and 3. The difference in grid parity cost at each building is weighted by annual electric demand of that building type in each state to produce Error! Reference source not found.. States highly amenable to fuel cells in Scenarios 1 and 2 see a substantial reduction in the grid parity cost due to the increased size, while 16 states see a net increase in parity cost. States with high energy costs and low base load percentages, saw an increase in both net savings grid parity price. Applications with highly predictable demand profiles such as small healthcare (out-patient) facilities and 'big-box' retail outlets would benefit most from diurnal dispatch control.

*** Insert Figure \#7 here **

Emissions, which decreased an average of $29.2 \%$ with the base-load generation, decreased an average of $56.3 \%$ with the diurnal dispatch strategy. The average commercial building self-generation increased from $42.7 \%$ to $80.2 \%$. The large reduction in emissions stems from the heat recovery and greater displacement of coal power and is in line with previous case studies [35]. A larger installation size generates additional heat to offset more of the winter heating loads present throughout much of the country.

Scenario 5 analyzes a slightly larger system controlled to follow demand, subject to ramping constraints. The results are similar to Scenario 3. Meeting more of the morning and evening demands increases the self-generation to $85 \%$. Combined with the capacity to mitigate demand charges, annual grid charges decrease by $20 \%$. Distributing the cost savings amongst a $28 \%$ increase in installation size, amounts to a $7 \%$ reduction in grid parity price between Scenarios 3 and 5. Emission reductions further increased from $56 \%$ to $64 \%$ due to the additional heating emissions and high proportion of on-peak electricity offset by the load-following FC system. Apartments and hotels see the greatest benefit from this strategy due to the shoulder peaks in demand (e.g. 6-9AM and 6-9PM) not met by the diurnal dispatch method.

\subsection{Electricity Sell-back}

Scenario 4 considers the possibility of selling excess electricity back to the grid at $50 \%$ of the retail rate. This challenges utilities to further reduce generation during off-peak and winter seasons, but incentivizes larger selfgeneration installations which can alleviate summer peak capacity concerns. Fuel cells benefit from a net-metering program in most states, Error! Reference source not found.. Sell-back allows for installation of a larger base load system, and load following systems offer the potential to contribute as a dispatchable grid resource [3]. The high efficiency conversion of gas to electricity of the FC system results in low marginal generation costs which, even at 
$50 \%$ of retail electricity rates, can generate revenue in some high cost electricity markets. This is especially true for TOU rates during the summer peak periods. Once again, states that were highly amenable to stationary fuel cells in scenario 2, see a further reduction in net building energy costs by introducing a larger system that can export power in Scenario 4, but see a lower grid parity cost due to the larger installation.

\section{*** Insert Figure \#8 here **}

DG-BEAT has the ability to perform a cost optimization that minimizes the net present cost for the building with a DG system by varying the size of the system between the base load and the peak load. A modified Newtonian search method identifies the optimal size $\pm 0.1 \%$. In cases in which a FC system is not economically beneficial, this algorithm will result in a very small system. In cases with a small economic benefit from sellback, the size may only increase slightly from the baseload size of Scenarios 1 and 2. In other cases the size increased sufficiently to transform the building into a net exporter of electricity. In no cases could a fuel cell system generate electricity at $50 \%$ of the local utility rate. The export of electricity arises from the low marginal cost of generation and the excess capacity throughout the day when the system is sized to meet the building's peak electricity demand.

From Error! Reference source not found., Error! Reference source not found., and Error! Reference source not found. we can infer that in New York a fuel cell costing between $\$ 7,000$ and $\$ 9,000$ per $\mathrm{kW}$ would break even operating as smaller base load unit. At a cost between $\$ 5,000$ and $\$ 7,000$ per $\mathrm{kW}$ a larger base load system exporting power at $50 \%$ of the retail price would break even. At $\$ 5,000$ per $\mathrm{kW}$ a larger fuel cell system could break even without exporting power if it were capable of some degree of scheduling or load following. Therefore, at an installed cost of $\$ 5,000$ per $\mathrm{kW}$ a small base load system may still be preferred as it would save more than $\$ 2,000$ per $\mathrm{kW}$ over the 10 year lifespan of the system. However, the larger system displaces a greater portion of the electric charges and electric emissions, and will thus accrue additional savings over the smaller system as they continue to operate beyond 10 years. At an installed cost at or below $\$ 3,500$ per $\mathrm{kW}$ the total savings over the first 10 years is greater for the larger system than the small baseload system, and the emissions savings may double.

In Colorado a different picture emerges. The base load grid parity cost is considerably lower, ranging from $\$ 2,000$ to $\$ 4,500$ for different buildings self-generating between $30 \%$ and $52 \%$ of their electricity demand. The grid parity price is the same for a larger fuel cell operated dynamically or as an exporter. From these two specific cases, and other states, we can surmise that increasing the capacity from $40 \%$ to $80 \%$ of annual electric demand equates to a net present value of $\$ 3,000-\$ 4,000$ per $\mathrm{kW}$ of dispatchable power. This rate brings down the average parity price of a fuel cell system in New York, and is directly in line with the parity price of a base load system in Colorado.

\subsection{Complimentary Technologies}

The factor in DG-BEAT analyses that has the second largest impact, after energy costs, is climate. Error! Reference source not found. presents a map of the proportion of annual electric use devoted to air conditioning. Climate particularly affects the impact of thermal storage and absorption chillers that are analyzed in Scenario 6.

\section{*** Insert Figure \#9 here **}

In warm climates thermal storage can reduce peak cooling demand by $57 \%$ [6], allowing smaller chillers to be installed. This scenario considers the addition of both electric chillers and thermal storage to the installation of a stationary fuel cell. The fuel cell installation remains the same size as that of Scenarios 1 and 2, thus any differences are directly attributable to the chillers and thermal storage technologies included in the balance of system. The coldwater thermal storage is sized to meet the on-peak cooling demand of the most severe summer day. The chillers were sized to meet the off-peak cooling demand and charge the cold-water tank. An optimization of the cold-water storage and chiller sizing was not conducted but is discussed in the literature [14].

Error! Reference source not found. presents the grid parity cost results of scenario 6 . The benefits of thermal storage can be seen throughout the Southeast, the Midwest and Arizona. This analysis did not consider removal of the original HVAC system, thus the $\$ 350$ per ton refers to the additional cost of installing efficient centrifugal electric chillers in addition to any existing HVAC units. Despite these additional installation costs the savings were considerable; largely associated with shifting electric demand from on-peak to off-peak hours. In hot and humid climates there is sufficient economic benefit associated with sizing a cold-water storage system to nearly completely 
levelize the summer electricity demand of the building. Because Scenario 6 sizes the chiller and thermal energy storage to completely levelize the summer electricity demand of each building type there is little difference in the sizing, operation, or financial results from the different control strategies.

$* * *$ Insert Figure \#10 here **

Without thermal storage and district cooling the state of Florida realizes no net benefit in energy costs when a stationary fuel cell is installed. With thermal storage the state electricity costs reach parity with a fuel cell system at an installed cost of $\$ 3500 / \mathrm{kW}$. Net annual carbon emissions were reduced $35-45 \%$ with the use of fuel cells and thermal storage. The additional $10 \%$ reduction with respect to scenario 2 is directly attributable to the installation of thermal storage. These results are in-line with the emissions analyses of others [6].

Error! Reference source not found. presents a strong net impact on the commercial building sector in the Southeast, but the impact is much greater for certain building types with high air-conditioning loads. Error! Reference source not found. takes a closer look at the results for the 16 building varieties in Florida, comparing the increase in grid parity cost (solid bars) to the proportion of electric load associated with air conditioning (dashed bars).

Buildings with greater than $30 \%$ of their electric demand from air conditioning (e.g. secondary schools, hotels, and outpatient facilities) result in the highest FC grid parity costs; $\$ 7,000$ to $\$ 9,000$ per kW. For these buildings this configuration of a stationary fuel cell paired with electric chillers and cold-water storage (Scenario 6) is comparable to the high value markets of New York and California identified in Scenarios $1 \& 2$.

*** Insert Figure \#11 here **

The final scenario analyzed was the combination of a fuel cell and absorption chiller (Scenario 7). An absorption chiller utilizes the waste heat to generate cooling for a building and can result in net CHP efficiencies as high as $87 \%$ [8]. Absorption chillers have been considered excellent candidates for integration with a CHP fuel cell due to the well suited temperature of the MCFC or SOFC exhaust, though some bypass or dilution may be required to integrate offthe-shelf systems [9]. The absorption chiller cannot replace the existing HVAC system, but can supplement it when electric and cooling demands are coincident. An absorption chiller reduces the net electric use of a building and avoids potential greenhouse gas and pollutant emissions.

However, as Error! Reference source not found. and demonstrate, at an installed cost of $\$ 750$ per ton an absorption chiller does not save money in any state or at any particular commercial building category. The emissions savings are negligible in this scenario. Buildings such as hospitals, hotels, and supermarkets are the most likely to benefit from an absorption chiller installation, albeit at a lower cost.

$* * *$ Insert Figure \#12 here **

These results are in line with previous studies by Medrano et al [36]. The negative value proposition result is somewhat surprising, as the utilization of free waste heat to generate cooling is fundamentally beneficial. However, the dynamics of the building demand profiles resulted in either low utilization factors for the absorption chiller or an undersized chiller that could not generate enough cost savings. Further analysis with detailed integration into the HVAC dispatching might result in a more favorable system design for an absorption chiller.

*** Insert Table \#4 here **

\section{Summary and Conclusions}

This paper presented seven scenarios for stationary fuel cell integration into the U.S. commercial building stock. A significant regional variability in the economic viability of stationary fuel cell systems was determined to be largely dependent upon the energy cost difference between gas and electric energy rates. The strengths of many initial markets (e.g. California, New York, Connecticut) were affirmed while additional states such as Michigan demonstrated strong potential for economic benefit with current stationary fuel cell prices. 
Time-of-use pricing played a strong part in determining the optimal dispatch strategy. When installed system cost dips below $\$ 5,000$ many building/market combinations can realize additional cost and emission reductions by selfgenerating as much as $85 \%$ of their electricity demand using larger systems with dynamic dispatch capability.

Building dynamics played an important role in determining types of commercial buildings that are most amenable to stationary fuel cell installations. Buildings with large base loads such as supermarkets, hotels, and apartment buildings most often realized the most benefit. Sell-back of electricity, at $50 \%$ of retail prices, increased the optimal size of building FC installations by as much as $130 \%$ in high cost energy markets, but had negligible impact in low cost energy markets.

Climate played a large role in the viability of balance of system technology, noticeably improving the economics of installations with integrated cold-water storage in the Southeast.

\section{Acknowledgements}

The authors gratefully acknowledge and recognize the technical contributions of Sam Sprik, Genevieve Saur, Mike Penev and Darlene Steward at the National Renewable Energy Laboratory. We also gratefully acknowledge the funding and technical support from the U.S. Department of Energy and our contract manager Jason Marcinkoski.

\section{References}

[1] Dustin McLarty, Jack Brouwer, and Chris Ainscough, "Development of an open access tool for design, simulated dispatch, and economic assessment of distributed generation technologies" Energy and Buildings, Online July 31, 2015, doi:10.1016/j.enbuild.2015.07.064

[2] Kristopher A. Pruitt, Robert J. Braun, and Alexandra M. Newman, "Establishing conditions for the economic viability of fuel cell-based, combined heat and power distributed generation systems," Applied Energy, vol. 111, pp. 904-920, November 2013.

[3] Kimihiro Nanaeda, Fabian Mueller, Jacob Brouwer, and Scott Samuelsen, "Dynamic modeling and evaluation of solid oxide fuel cell - combined heat and power system operating strategies," Journal of Power Sources, vol. 195, no. 10, pp. 3176-3185, May 2010.

[4] Brendan Shaffer and Jacob Brouwer, "Feasibility of solid oxide fuel cell dynamic hydrogen coproduction to meet building demand," Journal of Power Sources, vol. 248, pp. 58-69, February 2014.

[5] A. Nakajo et al., "The effects of dynamic dispatch on the degradation and lifetime of solid oxide fuel cell systems," Journal of the Electrochemical Society, 2011.

[6] Ayman Al-Qattan, Abdelrahman ElSherbini, and Kholoud Al-Ajmi, "Solid oxide fuel cell application in district cooling," Journal of Power Sources, vol. 257, pp. 21-26, July 2014.

[7] M. Stadler et al., "Electric storage in California's commercial buildings," Applied Energy, vol. 104, pp. 711-722, April 2013.

[8] Florian Zink, Yixin Lu, and Laura Schaefer, "A solid oxide fuel cell system for buildings," Energy Conversion and Management, vol. 48, no. 3, pp. 809-818, March 2007.

[9] Pere Margalef and Scott Samuelsen, "Integration of a molten carbonate fuel cell with a direct exhaust absorption chiller," Journal of power Sources, vol. 195, no. 17, pp. 5674-5685, September 2010.

[10] Michael Deru, Kristin Field, Daniel Studer,Kyle Benne, Brent Griffith, and Paul Torcellini, "U.S. Department of Energy Commercial Reference Building Models of the National Building Stock," National renewable Energy Laboratory, Golden, NREL/TP-5500-46861, 2011.

[11] P. Torcellini et al., "DOE Commercial Building Benchmark Models," in 2008 ACEEE Summer Study on Energy efficiency in Buildings, Pacific Grove, 2008.

[12] D. McLarty, J. Brouwer, and GS Samuelsen, "A spatially resolved physical model for transient system analysis of high temperature fuel cells," International Journal of Hydrogen Energy, vol. 38, no. 19, pp. 7935-7946, June 2013.

[13] D. McLarty, J. Brouwer, and GS Samuelsen, " Fuel cell-gas turbine hybrid system design part II: Dynamics and control," Journal of Power Sources, vol. 254, pp. 126-136, May 2014. 
[14] D. McLarty, C. Civit Sabate, J. Brouwer, and F. Jabbari, "Micro-grid energy dispatch optimization and predictive control algorithms; A UC Irvine case study," International Journal of Electrical Power \& Energy Systems, vol. 65, pp. 179-190, February 2015.

[15] C.W. Potter et al., "Creating the Dataset for the Western Wind and Solar Integration Study (U.S.A.)," Wind Engineering, vol. 32, no. 4, pp. 325-338, 2008.

[16] "Eastern Wind and Transmission Study," National Renewable Energy laboratory, Golden, NREL/SR-5500-47078, 2011.

[17] US Department of Energy. (2014, August) Database of State Incentives for Renewables and Efficiency. [Online]. http://www.dsireusa.org/

[18] United States Environmental Protection Agency, "Clean Air Interstate Rule, Acid Rain Program, 2012 Progress Report: SO2 and NOx Emissions, Compliance, and Market Analyses" 2013 http://www.epa.gov/airmarkets/progress/ARPCAIR_12_downloads/ARPCAIR12_01.pdf

[19] "UTC fuel cell powers Price Chopper supermarket," Fuel Cells Bulletin, vol. 2010, no. 2, pp. 6-7, February 2010.

[20] E.J. Naimaster IV and A.K. Sleiti, "Potential of SOFC CHP systems for energy-efficient commercial buildings," Energy and Buildings, vol. 61, pp. 153-160, June 2013.

[21] "ClearEdge CHP units for historic Palace Hotel in Long Beach," Fuel Cells Bulletin, vol. 2011, no. 8, p. 4, August 2011.

[22] Sandra Curtin, Jennifer Gangi, and Ryan Skukowski, "The Business Case for Fuel Cells 2012," Breakthrough Technologies Institute, Washington D.C., 2012. [Online]. http://www.fuelcells.org/uploads/FC-Business-Case2012.pdf

[23] A.A Trendwiscz and R.J. Braun, "Techno-economic analysis of solid oxide fuel cell-based combined heat and power systems for biogas utilization at wastewater treatment facilities," Journal of power Sources, vol. 233, pp. 380-393, 2013.

[24] U. Benz, D. Busche, and D. Lutterbeck, "APPLICATIONS - STATIONARY | Uninterruptible and Back-up Power: Fuel Cells," in Encyclopedia of Electrochemical Power Sources, Jürgen Garche, Ed., 2009, pp. 135-145.

[25] Xuping Li, Joan M. Ogden, and Christopher Yang, "Analysis of the design and economics of molten carbonate fuel cell tri-generation systems providing heat and power for commercial buildings and H2 for FC vehicles," Journal of Power Sources, vol. 241, pp. 668-679, November 2013.

[26] I. Staffell and R.J. Green, "Estimating future prices for stationary fuel cells with empirically derived experience curves," International Journal of Hydrogen Energy, vol. 34, no. 14, pp. 5617-5628, July 2009.

[27] Ian Staffell. and Richard green., "The cost of domestic fuel cell micro-CHP systems," International Journal of Hydrogen Energy, vol. 38, no. 2, pp. 1088-1102, January 2013.

[28] Ayman Al-Qattan, Abdelrahman ElSherbini, and Kholoud Al-Ajmi, "Solid oxide fuel cell application in district cooling," Journal of Power Sources, vol. 257, pp. 21-26, July 2014.

[29] Jarosław Milewski, Marcin Wołowicz, Łukasz Szabłowski, and Jerzy Kuta, "Control Strategy for a Solid Oxide Fuel Cell Fueled by Natural Gas Operating in Distributed Generation," Energy Procedia, vol. 29, pp. 676-682, 2012.

[30] Quick Reference for Efficient Chiller System Design https://www.trane.com/commercial/uploads/pdf/865/ctv-trt-001-en.pdf

[31] Thermal Energy $\quad$ Storage $\quad$ Technology Brief available online at http://www.irena.org/DocumentDownloads/Publications/IRENAETSAP\%20Tech\%20Brief\%20E17\%20Thermal\%20Energy\%20Storage.pdf

[32] Laboratories for the 21st Century: Best Practices, Available on-line at http://www.nrel.gov/docs/fy11osti/50686.pdf

[33] Manufacturing cost analysis of $1 \mathrm{kw}$ and $5 \mathrm{kw}$ solid oxide fuel cell (SOFC) for auxilliary power applications. http://energy.gov/sites/prod/files/2014/06/f16/fcto battelle_cost_analysis_apu_feb2014.pdf

[34] Fuel Cell Technologies Office, "State of the States: Fuel Cells in America 2013," U.S. Department of Energy Office of Energy Efficiency and Renewable Energy, 2013. [Online]. http://www1.eere.energy.gov/hydrogenandfuelcells/pdfs/state_of_the_states_2013.pdf 
[35] G. Saur, J. Kurtz, C. Ainscough, and M. Peters, "Stationary Fuel Cell System Composite Data Products," National Renewable Energy Laboratory, Golden, NREL/TP-5400-61926, August 2014. [Online]. http://www.nrel.gov/docs/fy14osti/61926.pdf

[36] Girish Upreti, David L. Greene, K.G. Duleep, and Rapinder Sawhney, "Fuel cells for non-automotive uses: Status and prospects," International Journal of Hydrogen Energy, vol. 37, no. 8, pp. 6339-6348, April 2012.

[37] Yingjun Ruan et al., "Optimal option of distributed generation technologies for various commercial buildings," Applied Energy, vol. 86, no. 9, pp. 1641-1653, September 2009.

[38] Iain Staffell and Richard Green, "The cost of domestic fuel cell micro-CHP systems," International Journal of Hydrogen Energy, vol. 38, no. 2, pp. 1088-1102, January 2013.

[39] Jarosław Milewski, Marcin Wołowicz, Łukasz Szabłowski, and Jerzy Kuta, "Control Strategy for a Solid Oxide Fuel Cell Fueled by Natural Gas Operating in Distributed Generation," Energy Procedia, vol. 29, pp. 676-682, 2012.

[40] E.J. Naimaster and A.K. Sleiti, "Potential of SOFC CHP systems for energy-efficient commercial buildings," Energy and Buildings, vol. 61, pp. 153-160, June 2013. 


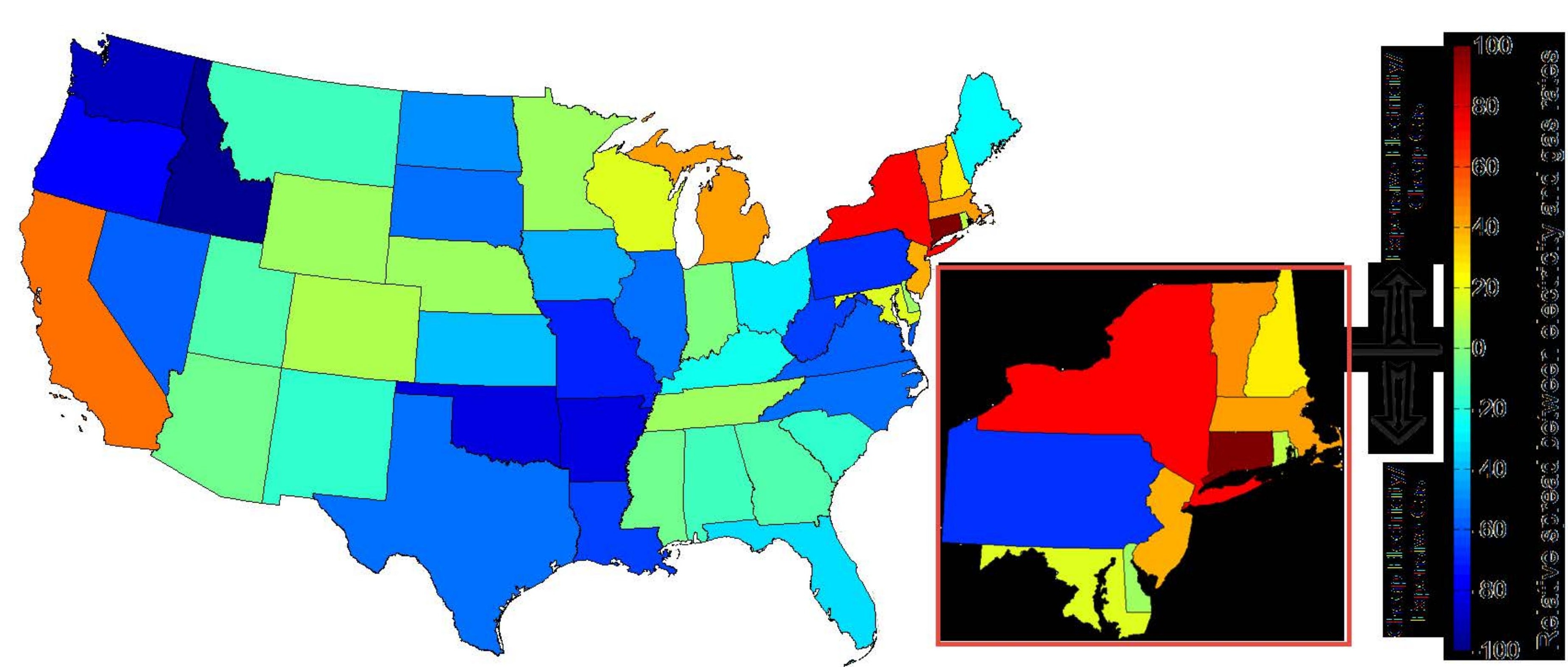




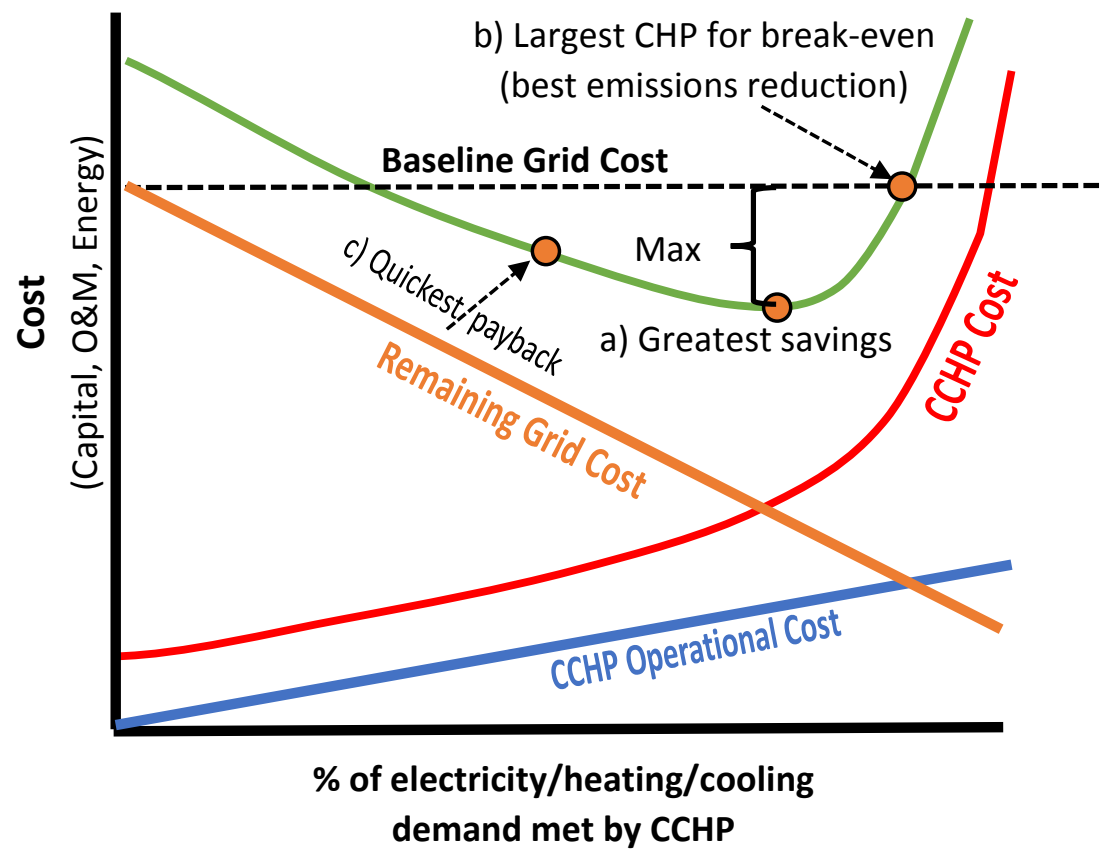




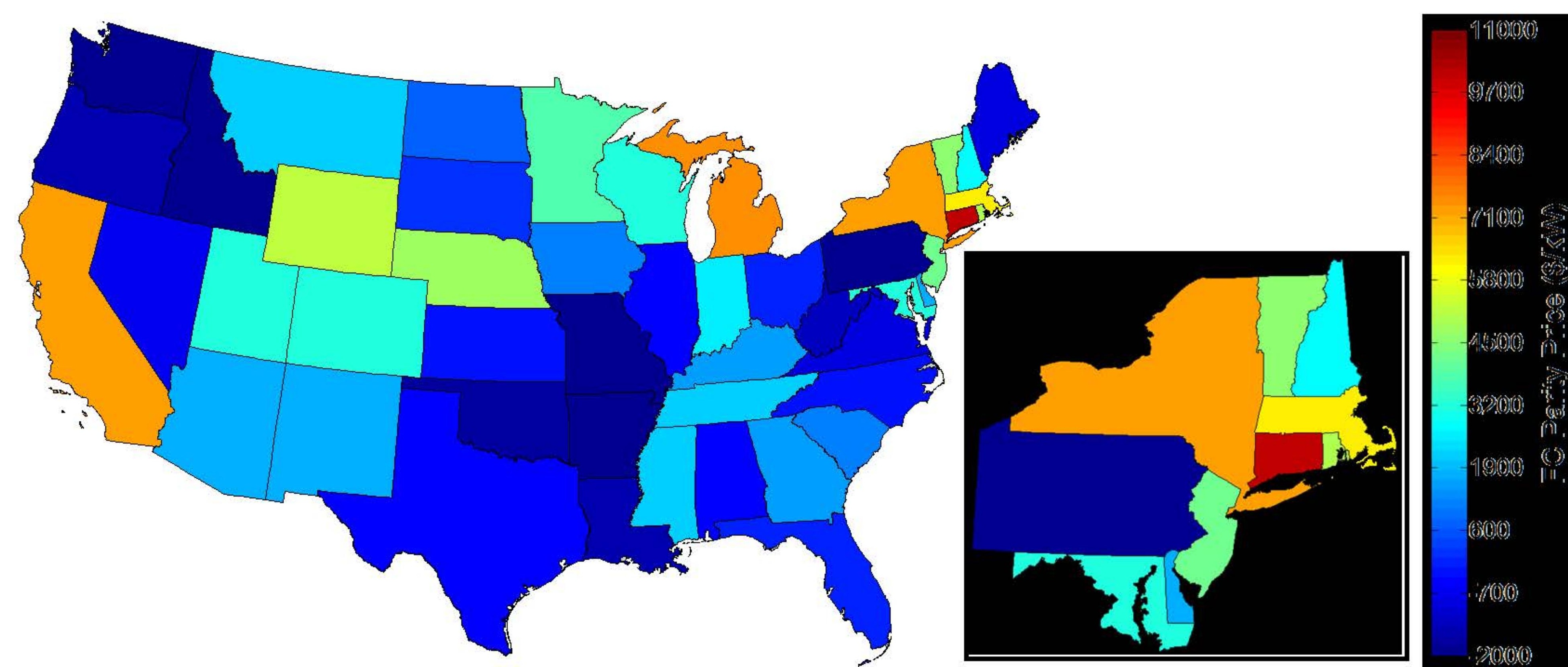


Figure 4

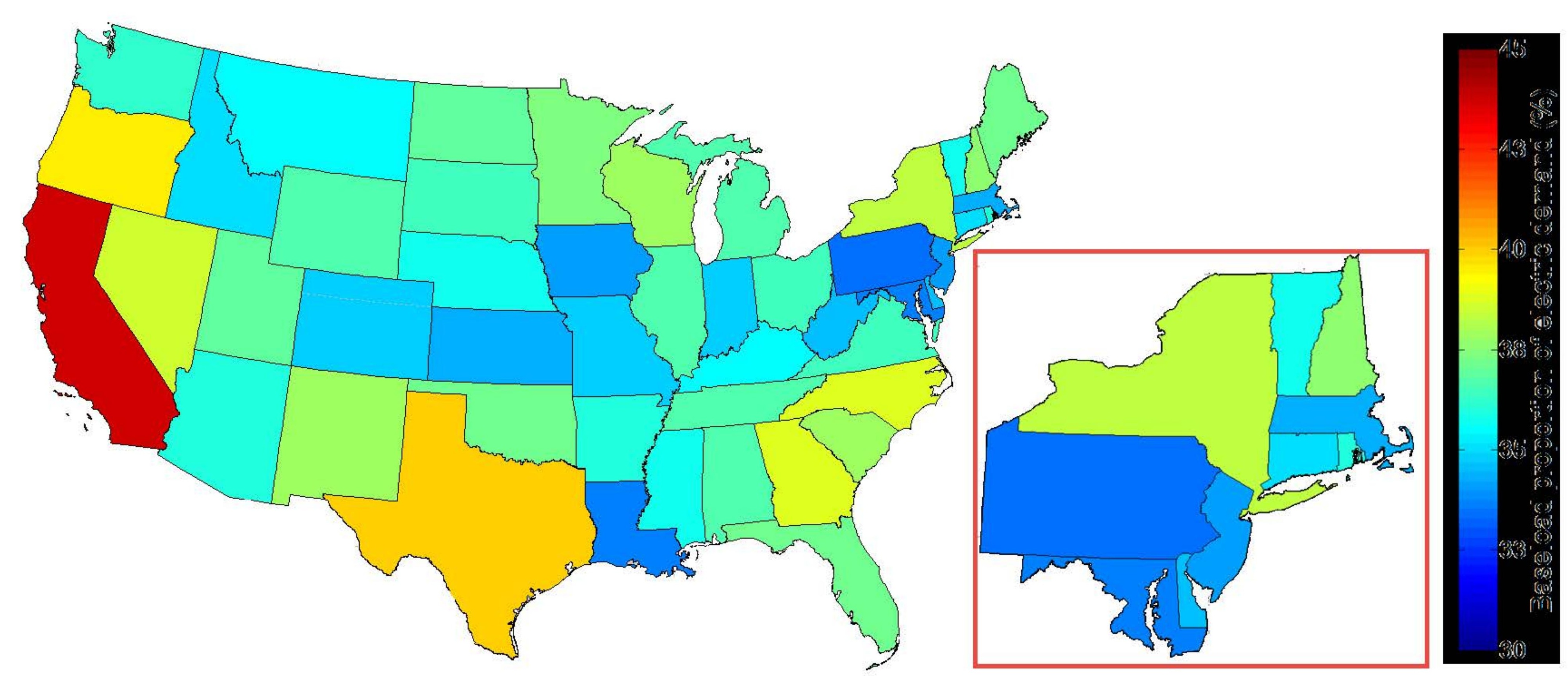




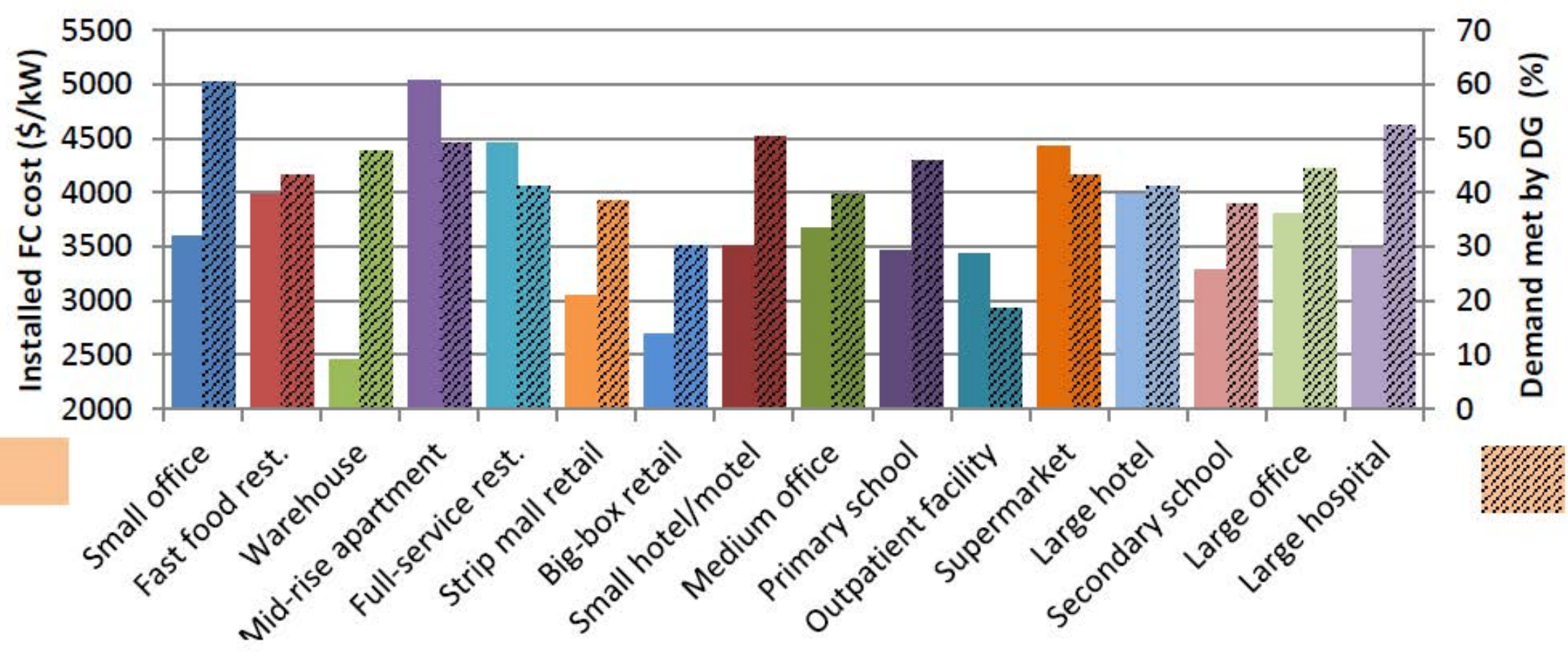




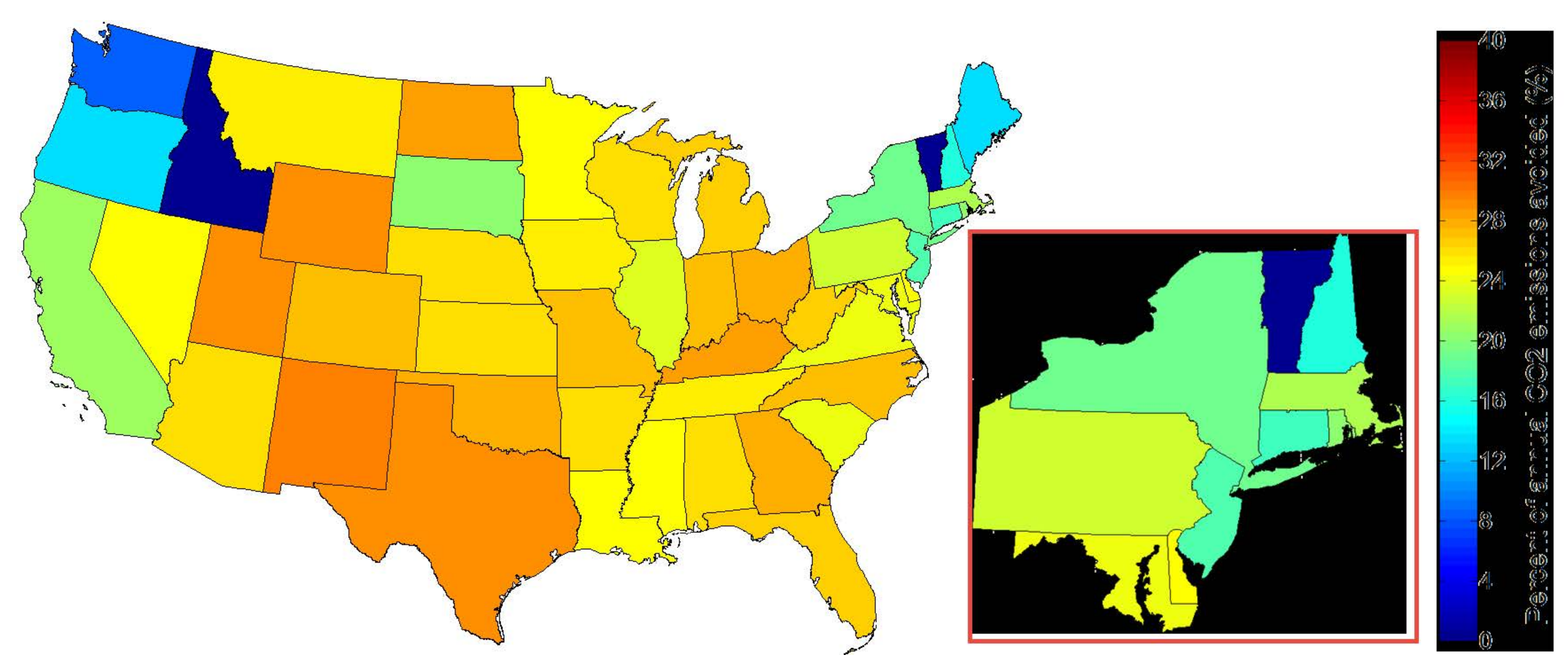




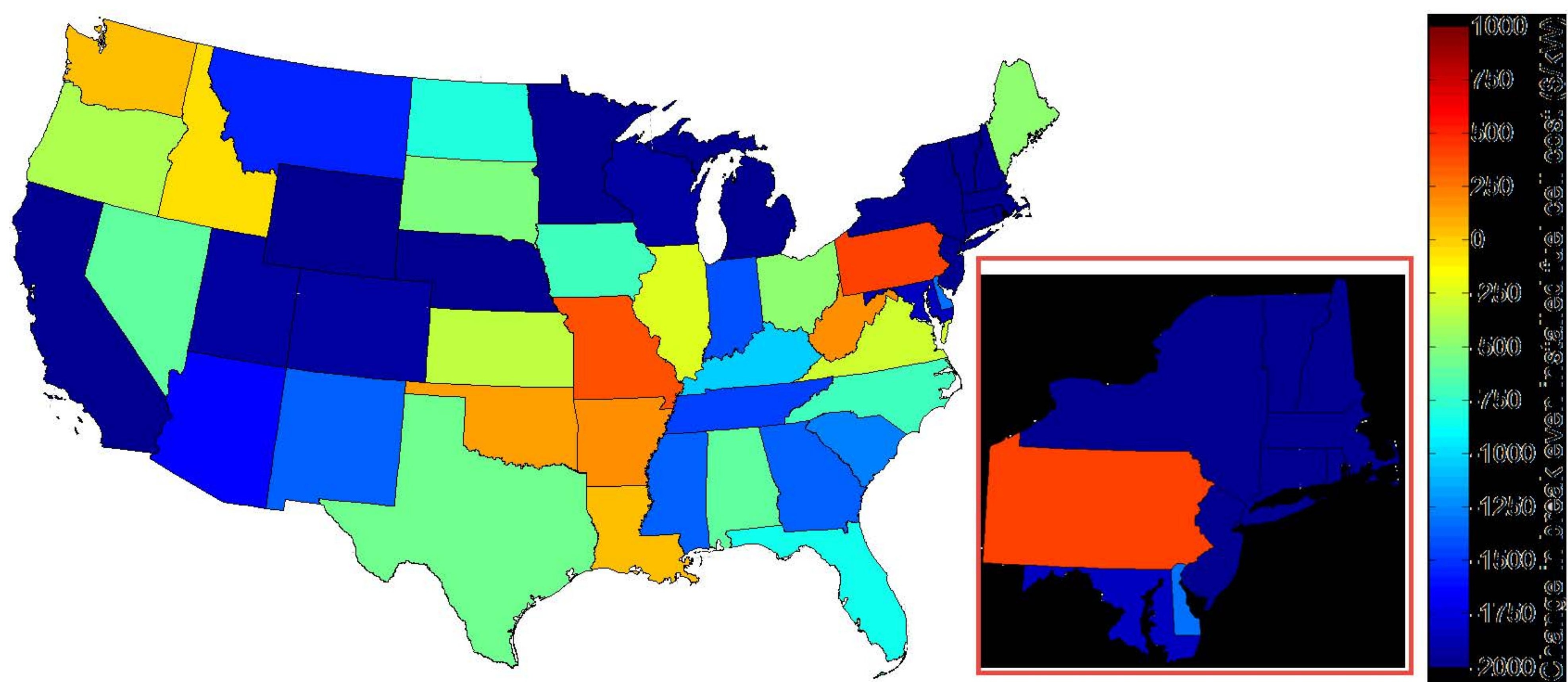




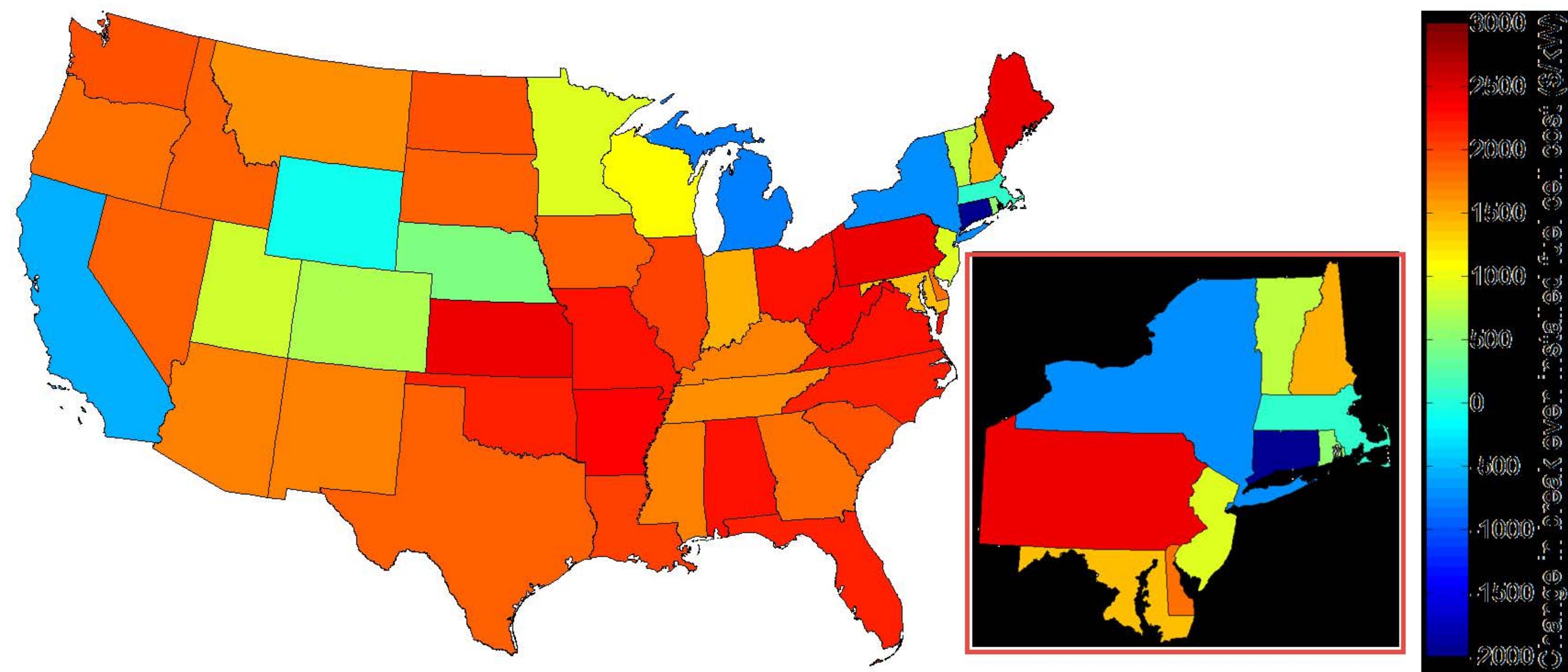




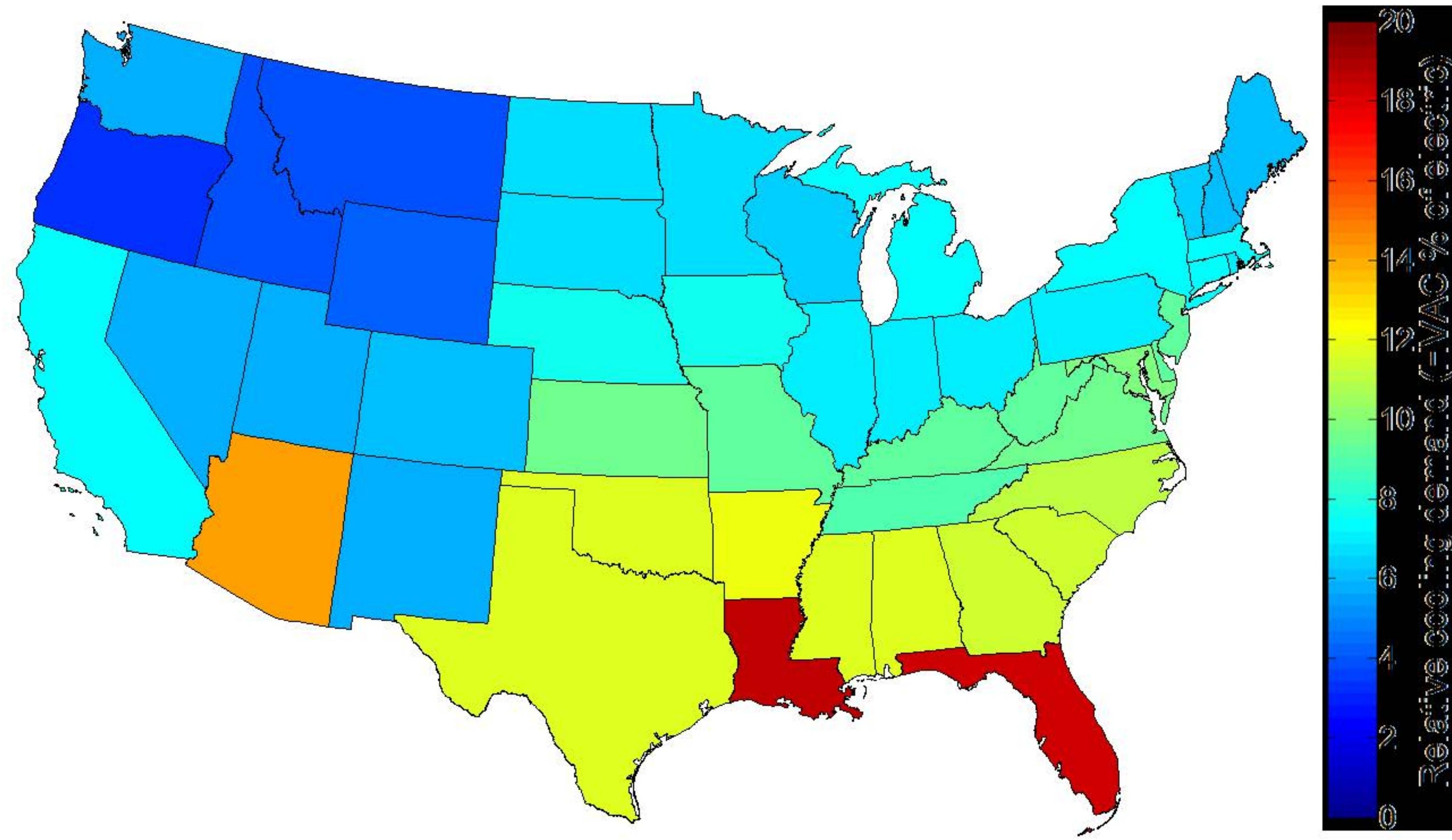




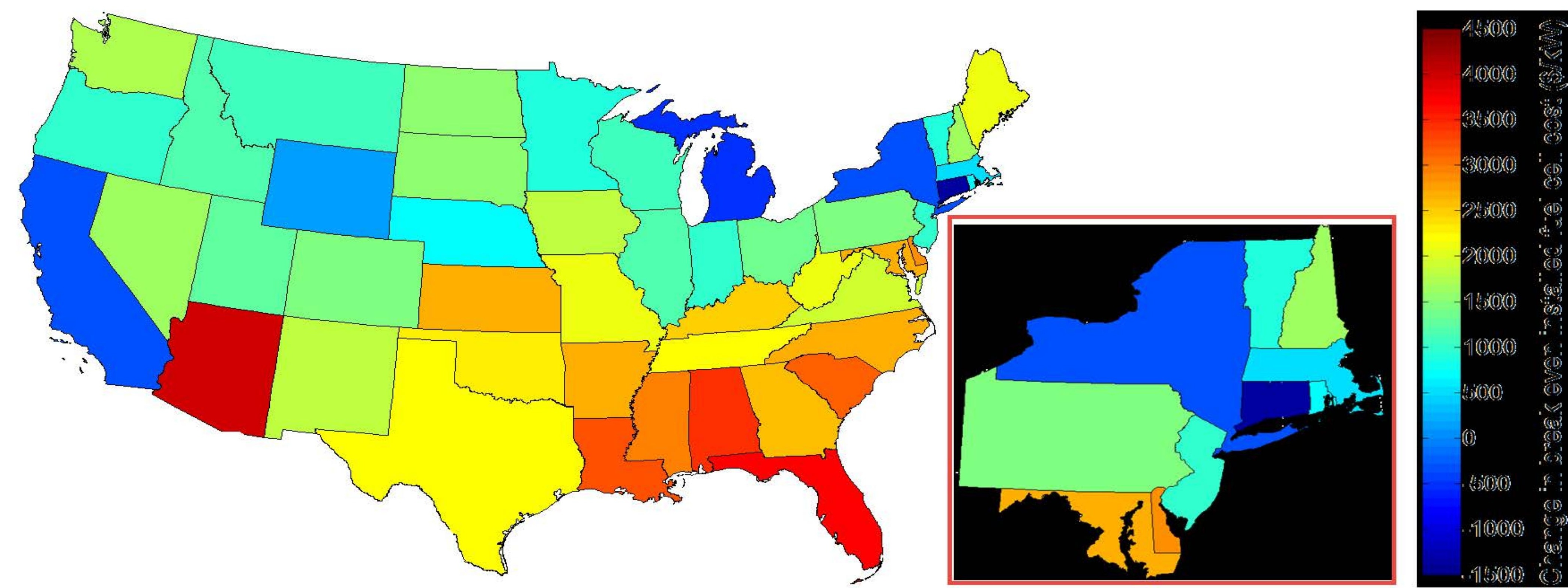


Figure 11
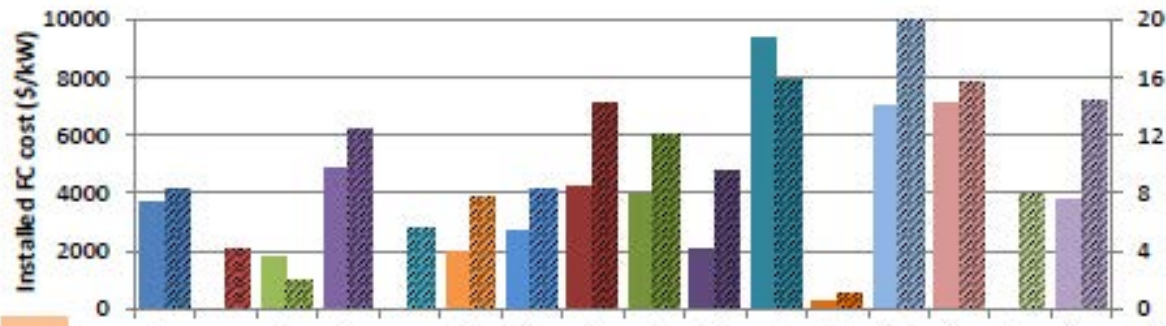

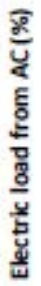
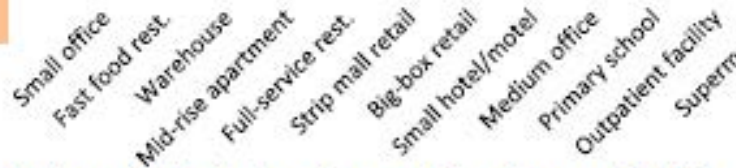

Fig. 11. Air conditioning loads and impact of themal storage in Florida
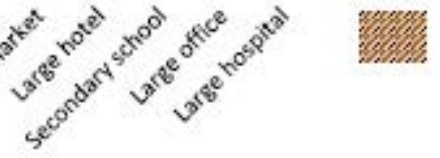

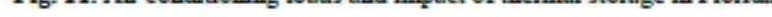




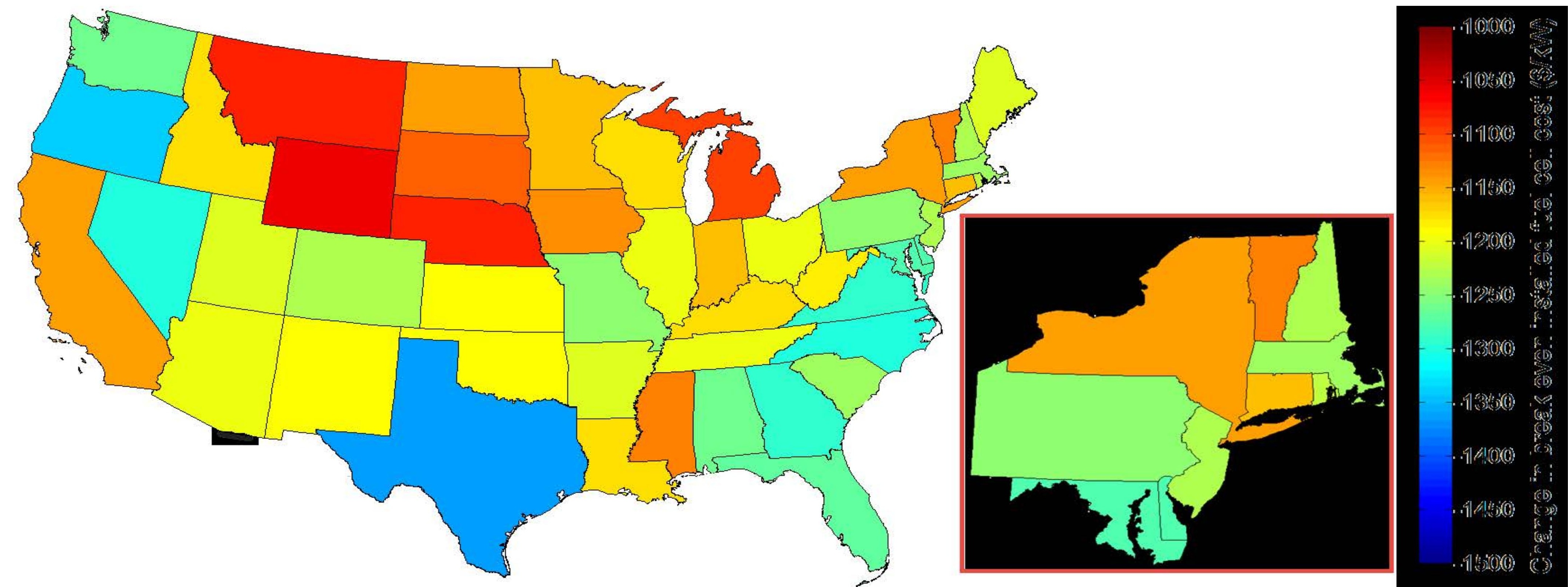

